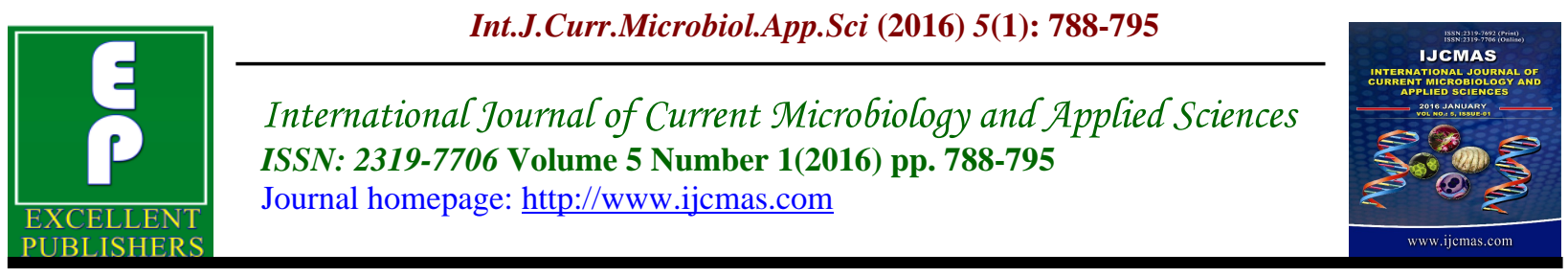

Original Research Article

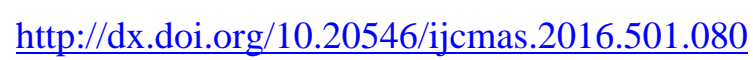

\title{
Studies on the Physicochemical and Biological parameters of River Vaigai, Madurai Dist, Tamilnadu, India
}

\author{
K. P. Karuppaiah ${ }^{1 *}$ and U. Ramesh ${ }^{2}$ \\ ${ }^{1}$ Research and Development, Bharathiar University, Coimbatore, India \\ ${ }^{2}$ Department of Molecular Biology, Madurai Kamaraj University, Madurai, India
}

*Corresponding author

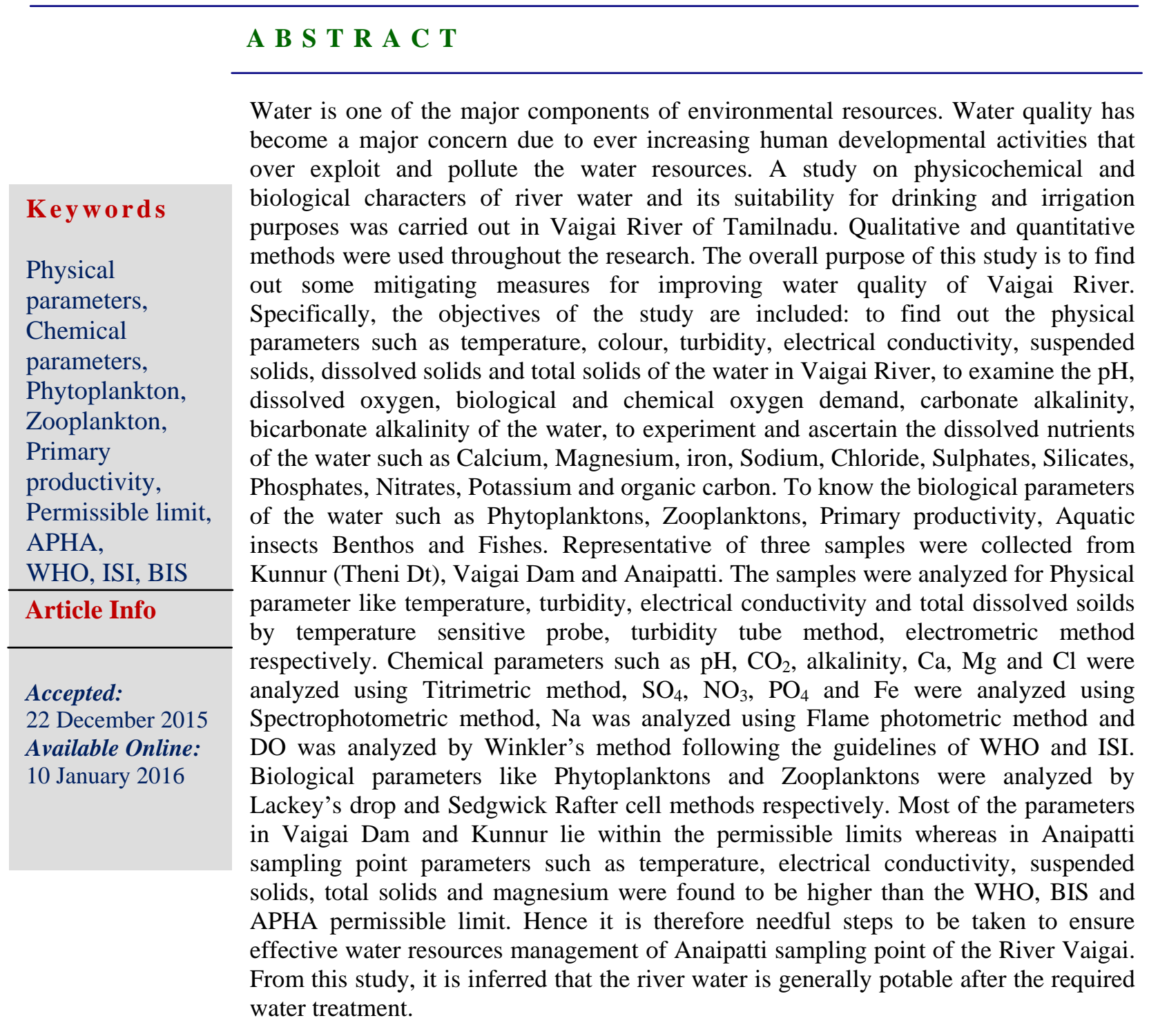




\section{Introduction}

The Vaigai is a river situated in Madurai, the Southern state of Tamil Nadu, India. It originates in the Periyar Plateau of the Western Ghats range, and flows northeast through the Cambam Valley, which lies between the Palani Hills to the north and Varushanad Hills to the South. The river empties into the Palk Strait in Ramanathapuram District. The Vaigai is 258 kilometers (160mi) long, with a drainage basin 7,031 square kilometers $(2,715 \mathrm{sq} \mathrm{mi})$ large. It falls within the co-ordinates of Latitude $7^{\circ} 21^{\prime} 00$ ' $\mathrm{N}$ and Longitude $79^{\circ} 00$ '00' $E$. Vaigai Dam is built across the Vaigai River flowing through Madurai, Pollution of rivers in India has now reached to a point of crisis due to unplanned urbanization and rapid growth of industrialization (Saksena et al., 2008). Many researchers have carried out research on water quality of rivers in different places and in each place it has received greater attention. For good and long life the good quality of water is very important. Present scenario Vaigai is mostly polluted by various pollutants and anthropogenic activities so with this aspect, this project focuses on the effect of pollutants in Vaigai river.

The main objectives of this study includes, to study the Vaigai River Ecosystem. Also, assessment of Water Quality in the Vaigai River. Effects of pollutants on the Biodiversity of Vaigai River. Then, Screening of pesticides Degrading Microorganisms Vaigai River.

\section{Materials and Methods}

\section{Sample Collection}

The water and sediment samples were collected from Vaigai River, Madurai, Tamil
Nadu, and India. Samples were collected for a period of one year with an interval of 30 days. Samples were collected in a fixed region of each sampling point. Every month sample was collected at the surface of the river at 11.30 to $12.30 \mathrm{pm}$ in order to maintain uniformity. Samples were collected in clean white polythene containers (1Lit Plastic cans). Collected samples were brought to the laboratory and kept in the refrigerator for further analysis,

Samples were collected from five different study sites included Vaigai dam, Annaipatti solavanthan, Aarappalayam, Anna Nagar.

\section{Methods for Physicochemical and Biological Analysis in Water and Sediments}

Temperature, color, Turbidity, Electrical conductivity, Suspended Solids, Dissolved Solids and Total solids. pH, Dissolved oxygen, Biological Oxygen Demand, Carbonate alkalinity, Bicarbonate alkalinity, Chemical Oxygen Demand. Phytoplanktons, Zooplanktons, Micro flora, Micro fauna, Primary productivity, Aquatic insects Benthos and Fishes.

\section{Result and Discussion}

\section{Physico Chemical Parameters of Study Sites (January to December 2014)}

\section{Temperature}

During the study period the water temperature was in range between $25^{\circ} \mathrm{C}$ to $32^{\circ} \mathrm{C}$. The lowest temperature recorded in the sampling point Vaigai Dam was $25{ }^{\circ} \mathrm{C}$. Study increase in water temperature was noticed in the River Vaigai from origin to Anaipatti. There might be increase in water temperature after discharge of effluents into the sampling points includes Anaipatti 
solavanthan, Arapalayam , Anna Nagar was recorded.

\section{Color}

The water flow in the river was found to be brownish in color during rainy season. In the sampling point Vaigai Dam it was found to be colorless in most of the months. In Anaipatti solavanthan, Arapalayam , Anna Nagar it was brownish in most of the months in water.

\section{Turbidity}

The turbidity value was in range between 14 - 22 N.T.U (Nephelometric Turbidity Unit) at Solavanthan. In the Vaigai Dam it ranges from 11 - 20 N.T.U. In Anaipatti, solavanthan, Arapalayam and Anna Nagar it was ranging from 25 to 32 N.T.U. The minimum turbidity value of (11 N.T.U) was recorded in Vaigai Dam. Whereas the maximum value of (32 N.T.U) was recorded in Arapalayam and Anna Nagar.

\section{Electrical Conductivity}

In the Solavanthan sampling unit electrical conductivity value of the water ranging from 180 to $270 \mu$ Mho. The electrical conductivity value of the Sampling point Vaigai Dam was ranging from 250 to 329 $\mu$ Mho. In Arapalayam, Anna Nagar the electrical conductivity values were ranging from 950 to $2900 \mu \mathrm{Mho}$. The minimum electrical conductivity value $(180 \mu \mathrm{Mho})$ was recorded at the sampling point Solavanthan and maximum electrical conductivity value of $(2900 \mu \mathrm{Mho})$ was recorded in the Arapalayam and Anna Nagar.

The value of total solids (suspended and dissolved) in Vaigai Dam, Anaipatti, Solavanthan, Arapalayam and Anna Nagar was ranging from 135 to310, 135 to 2815 ,
338 to 2965,350 to 2965 and 365 to 2965 $\mathrm{mg} / \mathrm{l}$ respectively. The lowest value (135 $\mathrm{mg} / \mathrm{l})$ was observed in Vaigai Dam and the highest value $(2965 \mathrm{mg} / \mathrm{l})$ was obtained from solavanthan, Arapalayam and Anna Nagar.

\section{pH}

The $\mathrm{pH}$ value of the sampling point Annaipatti solavanthan, Arapalayam, Anna Nagar was ranging from 7.5 to 8.1 . In the sampling point Vaigai Dam the $\mathrm{pH}$ value was ranging from 7.1 to 7.8 . The minimum $\mathrm{pH}$ value was recorded as 7.1 in the sampling points Vaigai Dam. The maximum $\mathrm{pH}$ was recorded at the sampling point Annaipatti solavanthan, Arapalayam, Anna Nagar. All the three sampling points showed an alkaline condition throughout the study period.

\section{Dissolved Oxygen}

The dissolved oxygen values were found to be ranging from 1.1 to $2.9 \mathrm{mg} / \mathrm{l}$ in the unit Arapalayam , Anna Nagar. In the Vaigai Dam sampling point the dissolved oxygen values were ranging from 4.1 to $6.4 \mathrm{mg} / \mathrm{l}$. In the sampling point Annaipatti solavanthan, ,, the dissolved oxygen values were ranging from 3.0 to $3.8 \mathrm{mg} / \mathrm{l}$. The minimum value $(0.3 \mathrm{mg} / \mathrm{l})$ was recorded at the sampling point Annaipatti solavanthan, Arapalayam , Anna Nagar, . Maximum value of $(6.4 \mathrm{mg} / \mathrm{l})$ was recorded in the sampling Vaigai Dam.

\section{Biological Oxygen Demand}

BOD values were ranging from 53 to 300 $\mathrm{mg} / \mathrm{l}$ in the sampling point Annaipatti solavanthan, Arapalayam , Anna Nagar. In the Vaigai Dam the BOD values were ranging from 9.5 to $16.8 \mathrm{mg} / \mathrm{l}$. In the sampling unit Annaipatti solavanthan, Arapalayam, Anna Nagar, the BOD. Values were ranging from 96 to $338 \mathrm{mg} / \mathrm{l}$. The minimum BOD. 
Table.1 Physico Chemical Parameters

\begin{tabular}{|c|c|c|c|c|c|c|c|c|c|}
\hline \multicolumn{10}{|c|}{ Physico Chemical Parameters } \\
\hline \begin{tabular}{|l} 
Sample \\
Sites
\end{tabular} & Temperature & pH & Alkalinity & Color & Turbidity & \begin{tabular}{|l} 
Electrical \\
Conductivity
\end{tabular} & DO & BOD & COD \\
\hline Vaigai Dam & $25-28$ & $\begin{array}{l}7.1- \\
7.8\end{array}$ & $4.1-6.4$ & Colourless & $14-22$ & $108-270$ & \begin{tabular}{|r}
$4.1-$ \\
6.4 \\
\end{tabular} & $\begin{array}{l}9.5- \\
16.8 \\
\end{array}$ & $12-62$ \\
\hline Anaipatti & $26-30$ & $7.5-$ & $2.0-3.8$ & $\begin{array}{l}\text { Brown } \\
\text { colour }\end{array}$ & $16-25$ & $250-329$ & $\begin{array}{c}3.0- \\
3.8\end{array}$ & $\begin{array}{l}96- \\
338\end{array}$ & $\begin{array}{l}110- \\
150\end{array}$ \\
\hline Solavandhan & $28-30$ & $\begin{array}{l}7.3- \\
7.9\end{array}$ & $3.0-3.9$ & $\begin{array}{l}\text { Brown } \\
\text { colour }\end{array}$ & $21-30$ & $280-2000$ & \begin{tabular}{|c|}
$2.0-$ \\
3.8
\end{tabular} & $\begin{array}{l}110- \\
338\end{array}$ & $\begin{array}{c}100- \\
150\end{array}$ \\
\hline Arapalaiyam & $25-32$ & $\begin{array}{l}7.3- \\
8.1\end{array}$ & $1.1-2$ & $\begin{array}{l}\text { Brown } \\
\text { colour }\end{array}$ & $26-32$ & $850-2900$ & $\begin{array}{c}0.3- \\
0.2\end{array}$ & $\begin{array}{l}53- \\
300\end{array}$ & $\begin{array}{l}160- \\
250\end{array}$ \\
\hline Anna Nagar & $30-32$ & $\begin{array}{l}7.5- \\
8.1\end{array}$ & $1.1-2.9$ & $\begin{array}{l}\text { Brown } \\
\text { colour }\end{array}$ & $29-32$ & $950-2900$ & $\begin{array}{c}0.3- \\
0.2\end{array}$ & $\begin{array}{l}45- \\
300\end{array}$ & $\begin{array}{l}173- \\
299\end{array}$ \\
\hline
\end{tabular}

Table.2 Micro organisms Isolated from Various Sites

\begin{tabular}{|c|c|c|c|}
\hline S. No & Sampling Location & Nature of sample & Microorganism Isolates \\
\hline 1 & Annaipatti & $\begin{array}{c}\text { Water \& } \\
\text { Sediment } \\
\end{array}$ & $\begin{array}{l}\text { V1 ,V2, V3 ,V4,V5,V 6,V7, V8, V9, V10, V11 } \\
\text {,V12, V13, V14, V15, V16,V17,V18, V19 }\end{array}$ \\
\hline 2 & Vaigai dam & $\begin{array}{l}\text { Water\& } \\
\text { Sediment }\end{array}$ & $\begin{array}{l}\text { V20, V21, V22, V23, V24, V25, V26, V27,V28, V29 } \\
\text {,V30 }\end{array}$ \\
\hline 3 & Sholavanthan & $\begin{array}{l}\text { Water \& } \\
\text { Sediment }\end{array}$ & $\begin{array}{l}\text { V31, V32, V33, V34, V35, V36, V37, V38, V39, } \\
\text { V40, V41, V42, V43, V44, V45, V46, V47, V48, } \\
\text { V49, }\end{array}$ \\
\hline 4 & Arapalayam & $\begin{array}{l}\text { Water \& } \\
\text { Sediment }\end{array}$ & $\begin{array}{l}\text { V50, V51, V52,V53,V54, V55, V56, V57, V58, V59, } \\
\text { V60, V61, V62, V63, V64,V65, V66, V67, V68, } \\
\text { V69, V70, V71, V72, V73, V74, V75, V76, V77, } \\
\text { V78, V79 }\end{array}$ \\
\hline 5 & Anna nagar & $\begin{array}{l}\text { Water \& } \\
\text { Sediment }\end{array}$ & $\begin{array}{l}\text { 80, V81, V82, V83, V84, V85, V86, V87, V88, } \\
\text { V89, V90, V91, V92, V93, V94, V94, V95, V96, } \\
\text { V97, V98, V99, V100, V101, V102, V103, V104, } \\
\text { V105. }\end{array}$ \\
\hline
\end{tabular}

Table.3

\begin{tabular}{l|l|l|l|}
$\begin{array}{l}\text { Site } \\
\text { ID }\end{array}$ & Sites & Latitude & Longitude \\
\hline 1 & Vaigai Dam & $10.05^{\circ} \mathrm{N}$ & $77.58^{\circ} \mathrm{E}$ \\
\hline 2 & Anaipatti & $9.8^{\circ} \mathrm{N}$ & $77.30^{\circ} \mathrm{E}$ \\
\hline 3 & Solavanthan & $9.9^{\circ} \mathrm{N}$ & $78.11^{\circ} \mathrm{E}$ \\
\hline 4 & Arapalayam & $9.9^{\circ} \mathrm{N}$ & $78.11^{\circ} \mathrm{E}$ \\
\hline 5 & Anna Nagar & $9.2^{\circ} \mathrm{N}$ & $78.14^{\circ} \mathrm{E}$ \\
\hline
\end{tabular}


Table.4

\begin{tabular}{|c|c|}
\hline Parameters & Method of Study \\
\hline \multicolumn{2}{|l|}{ Physical: } \\
\hline Turbidity, NTU & Turbidity tube method \\
\hline Colour & Eye Visualization \\
\hline Water temperature, ${ }^{\circ} \mathrm{C}$ & \multirow[t]{3}{*}{ EuTech Pc Tester35 Electrode Method } \\
\hline $\mathrm{EC}, \mathrm{m} \mathrm{S} / \mathrm{cm}$ & \\
\hline TDS, mg/L & \\
\hline \multicolumn{2}{|l|}{ Chemical: } \\
\hline $\mathrm{pH}$ & EuTech Pc Tester35 Electrode Method \\
\hline DO & Winkler's iodometric method \\
\hline \multicolumn{2}{|l|}{ BOD } \\
\hline COD & \\
\hline Total alkalinity, mg/L & Titrimetric method \\
\hline
\end{tabular}

Plate.1 Isolation of Bacteria from Water Samples Collected in Vaigai River
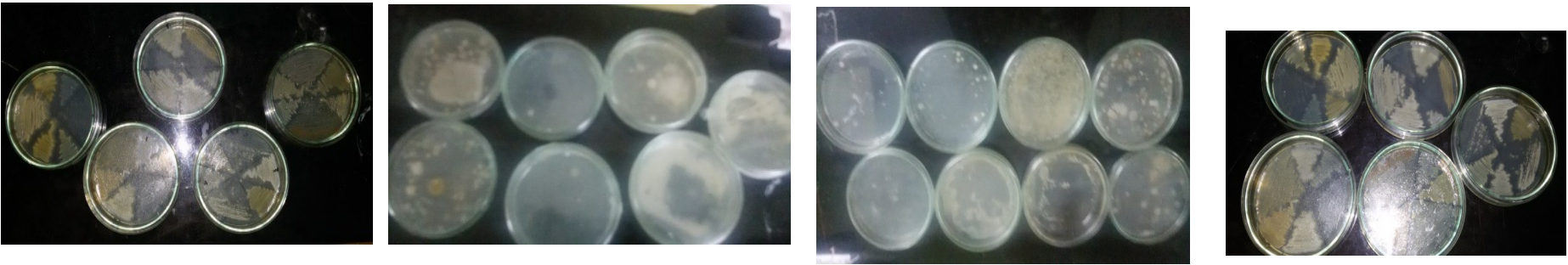

The value of $(9.5 \mathrm{mg} / \mathrm{l})$ was recorded at the sampling point Vaigai Dam and the maximum BOD. The value of $(338 \mathrm{mg} / \mathrm{l})$ was recorded in the Arapalayam, Anna Nagar.

\section{Bicarbonate Alkalinity}

Bicarbonate alkalinity value was ranging from 154 to $355 \mathrm{mg} / \mathrm{l}$ in the sampling point Anna Nagar. In Arapalayam sampling point the bicarbonate alkalinity value was ranging from 150 to $400 \mathrm{mg} / \mathrm{l}$. In the sampling point Vaigai Dam the bicarbonate alkalinity value was ranging from 80 to $280 \mathrm{mg} / \mathrm{l}$. In Anaipatti sampling point the bicarbonate alkalinity value was ranging from 175 to $479 \mathrm{mg} / \mathrm{l}$. In solavanthan sampling point the bicarbonate alkalinity value was ranging from 160 to $290 \mathrm{mg} / 1$.
The minimum bicarbonate alkalinity value of $(80 \mathrm{mg} / \mathrm{l})$ was recorded in the sampling unit Vaigai Dam and the maximum bicarbonate value of $(479 \mathrm{mg} / \mathrm{l})$ was recorded in the Annaipatti solavanthan, Arapalayam Anna Nagar.

\section{Chemical Oxygen Demand}

Chemical oxygen demand value was ranging from 173 to $299 \mathrm{mg} / \mathrm{l}$ in the sampling point Anna Nagar. In the Arapalayam COD value was ranging from 160 to $250 \mathrm{mg} / \mathrm{l}$. In the sampling point Vaigai Dam the COD value was ranging from 12 to $62 \mathrm{mg} / \mathrm{l}$. In the Annaipatti solavanthan, the value of COD was ranging from 110 to $150 \mathrm{mg} / \mathrm{l}$. The minimum COD value of $(12 \mathrm{mg} / \mathrm{l})$ was recorded in the sampling unit Vaigai Dam and the maximum COD value of $(426 \mathrm{mg} / \mathrm{l})$ 
was recorded in the. Annaipatti solavanthan Arapalayam Anna Nagar.

Fish

Puntius vittatus, Aplocheilus lineatus, Danio aequipinnatus, Etroplus suratensis, Loach leptocephalus thermalis, Labeo calbasu.

\section{Monitoring of Selected Microorganism in Vaigai River}

Sample Collection River water and sediments were dumping through the River' sampling port for 2-3 minutes prior to collection in sterile 1 liter wide-mouthed polypropylene bottles. Samples were placed on ice and returned to the laboratory for processing within 1-2 hours of collection.

\section{Isolation of Bacterial Species from Water and Sediments Samples}

The collected samples were serially diluted and the samples were spread plate for the growth of isolated colonies on LB agar. Then the plates were incubated at $37{ }^{\circ} \mathrm{C}$ for $24 \mathrm{hrs}$. After $24 \mathrm{hrs}$ the colonies grown on the plates were examined and the colonies were used for grams staining.

\section{Biochemical characterization}

Isolated bacterial colonies were used for biochemical tests like Indole, Methyl Red, Voges Proskauer, Ctrate Utilization, Coagulase, Catalase and Oxidase (above the Table). These biochemical characterizations results were used for identification of bacteria in genus level and species level characterization will be studied using $16 \mathrm{~s}$ rRNA sequence.

\section{Isolation of Pesticide Degrading Bacteria}

The procedure to isolate bacteria consisted of the addition of $0.1 \mathrm{~g}$ of ground to a flask containing $50 \mathrm{ml}$ of MSM medium, with 200mgl_1 of Monochrotophos 36\% SL pesticide model and as an insect inhibitor. Cultures were incubated at $301 \mathrm{C}$ and shaken at $100 \mathrm{rpm}$ for 7 days. Two milliliters were then transferred to a fresh MSM medium containing 200mgl_1 of PCNB and incubated under the same conditions. Cultures from the fifth transfer were plated on nutrient agar and incubated for $24 \mathrm{~h}$ at $30 \mathrm{1C}$. Colonies were isolated on the basis of morphological, culture, and biochemical characteristics using BBL Crystal GP System (Becton, Dickinson and Co., 2005). Bacterial isolates were plated separately on MSM medium containing 50ppm Monochrotophos 36\% SL, Cultures that were able to grow in all pesticides tested were used for further studies.

In conclusion, the results for the present study on Vaigai River indicate the need for comprehensive monitoring of this river. Proper management, decisions have to be taken for the restoration of River Vaigai at Arapalayam and Anna Nagar sampling unit, which had been threatened ecologically due to various anthropogenic activities. Concerned authorities of the Tamil Nadu Water Supply and Sewage Board have to take appropriate action by controlling the sewage and industrial effluent let into the Vaigai River of Arapalayam and Anna Nagar. Letting in treated water would maintain the water quality that will improve the aquatic biota. The Arapalayam and Anna Nagar sampling point needs immediate remedial actions against shoreline degradation.

\section{Acknowledgement}

Author are grateful to the Dr.U.Ramesh Assistance professor Department of Molecular Biology, Madurai Kamaraj University, Madurai, and Research and Development, Department Microbiology, Bharathiar University, Coimbatore 


\section{References}

Amaal M. Abdel Satar, 2005. Water quality assessment of River Nile from Idfo to Cairo, National Institute of Oceanography and Fisheries, Egy. J. of Aqua. Res., 31(2): 200 - 223.

Ananthan G., Sampathkumar P., P.Soundarapandian and waste-water. American Public Health Association, New York., 43(6): p.709.

Anil Kumar, Seema Tripathi and P. Ghosh, 2004. Status of freshwater in 21 century: a review. In Water Pollution: Assessment and Management (Edited by) Arvind Kumar and G. Tripathi. Daya Publishers, Delhi, p. 520.

Banik, S., 2002. Rotifera: Monogononta from freshwaters of Tripura, India. $J$. of Bombay Natural Hist. Society., 99(2): 262 - 266.

Barik, R.N. and Patel, R.K., 2004. Seasonal Variation of Water Quality of Atharabanki River near Paradip. Indian J. of Envi. Prot., 24(3): 161 166.

Bashar, M.A., Waidbacher and Ullah S.M., 2005. Environmental assessment of industrial effluents, Sewage sludges and harbour activities on river quality, Bangladesh. J. Asian Society Bangladesh Sci., 31: 1 - 14.

Bastia, A.K., Satapathy, D.P. and Adhikar, S.P., 1993. Heterotrophic growth of several filamentous Blue - Green Algae. Arch. Hydrobiol., 598: 65 - 70.

Battish, S.K. 1992. Fresh water zooplankton of India. Oxford and IBH Publishing Co.Pvt.Ltd., New Delhi., .3: 233 - 239.

Beasley, D.B. and Allen, J.B., 1974. A Characterization of the effluent from commercial Catfish Ponds. American Society of Agricultural Engineers, Paper no. 74 - 5004

Campos, Hugo Wladimir Stefen, Carlos Roman Luis, Zunija and Gloria
Agvero, 1983. Limnological studies in lake Valenzhia (Chile), morphometry, physical, chemical, planktonic and primary productivity. Arch. Hydrobiol. Suppl., 65(4): 371 - 406.

CBPCWP, 1985: Adsorption of treated or untreated organic load by the soil in term of BOD and COD, Indian Jour, Environ. Health, 8(1): 131 - 135.

Chacko, P.I. and Ganapathi, S.V., 1949. Some observations on the Adaiyar river with special references to its hydrobilogical conditions. Indian Geo J., 24: 35 - 49.

Ramteke, D.S. and Moghe, C.A., 1988. Manual on water and wastewater analysis. National Environmental Engineering Research Institute (NEERI), Nagpur.

Khatavkar, S.D. and Trivedy, R.K., 1992. Water quality parameters of River Panchaganga near Kolhapur and Ichalkaranji, Maharastra. India. $J$. Ecotoxicol. Environ. Monit., 2(2): 113 $-118$

Duzzin, B., Pavoni and Doonozolo, R., 1988: Macro - invertebrate communities and sediments as pollution indicator for heavy metal in the river Adige (Italy), Receiving Industrial effluents. Water, Res., 22(1): 1353 - 1358.

Edmondson, W.T., 1959. Freshwater Biology, 2nd edition. John Wiley \& Sons, Inc., New York. Edward, C.A., 1977. Persistent pesticides in the environment, C.R.C. Press, Cleaveland, Ohio.

Efe, S.T., 2002. Urban warming in Nigerian cities. The case of warri metropolis. African J. of Environ. Studies., 2(2): p. 6.

Efe, S.I., Ogban, F.E., Horsfall, M., Jnr and Akporhonor, E.E., 2005. Seasonal variations of physico - chemical Characteristics in water Resources 
Quality in Western Niger Delta Region, Nigeria. J. Appl. Sci. Environ. Mgt., 9(1): 191 - 195.

Zafar, A.R. 1964. On the ecology of algae in certain fish ponds of Hyderabad, India. I. Physico - Chemical complexes. Hydrobio., 23: 179 - 195.

Zehra, A.K. and Altaff, K., 2002. Redescription of Mesocyclops aspericornis (Daday, 1906. Copepoda: Cyclopoida) from an Indian pond. J. of
Plankton Research, 24: 481 - 493.

Zoufa, T.S., Scherman, P.A. and Palmer, C.G., 2001. Tolerance of selected riverine indigenous macro invertebrates from the Sabie River (Mpumalanga) and Buffalo River (Eastern Cape), to Complex Saline Kraft and textile effluents WRC Report No.783/01/01.

\section{How to cite this article:}

Karuppaiah, K. P., and Ramesh, U. 2016. Studies on the Physicochemical and Biological parameters of River Vaigai, Madurai Dist, Tamilnadu, India. Int.J.Curr.Microbiol.App.Sci. 5(1): 788-795. hittp:///dx.doi.org/10.20546/ijcmas.2016.501.080 